\title{
Instructional Games and Vocabulary Enhancement: Case of Iranian Pre-Intermediate EFL Learners
}

\author{
Hooshang Khoshsima ${ }^{1}$, Amin Saed ${ }^{1}$, Arash Yazdani ${ }^{2}$ \\ ${ }^{1}$ English Language Department, Chabahar Maritime University, Chabahar, Iran \\ ${ }^{2}$ MA. Student, Chabahar Maritime University, Chabahar, Iran
}

Email address:

khoshsima@cmu.ac.ir (H. Khoshsima),Amin.saed@cmu.ac.ir (A. Saed), Arash678@gmail.com (A. Yazdani)

\section{To cite this article:}

Hooshang Khoshsima, Amin Saed, Arash Yazdani. Instructional Games and Vocabulary Enhancement: Case of Iranian Pre-Intermediate EFL Learners. International Journal of Language and Linguistics. Vol. 3, No. 6, 2015, pp. 328-332. doi: 10.11648/j.ij11.20150306.12

\begin{abstract}
Vocabulary learning has always been a major concern for second language learners. Particularly for those who are just beginning to learn English. Usually a long list of vocabulary items is given to learners and they have to memorize all of them. The present study using a quasi-experimental design aimed to determine whether teaching vocabulary through instructional games can affect the vocabulary enhancement of students. The participants were 40 pre-intermediate EFL students who were equally divided into two groups. To this end, the two groups of students were assigned as control and experimental groups. The control group was exposed to textbook teaching and the experimental group was exposed to instructional games. After analyzing the obtained data, no significant differences were found between the two groups on posttest, as both programs made progress in the subjects. However, after two weeks, a delayed post-test was conducted to see the retention of learners' knowledge of vocabulary. In the end, although both groups had changed positively, a significant change was seen in the retention of learners' knowledge of vocabulary in the experimental group.
\end{abstract}

Keywords: Instructional Games, Vocabulary Learning, Traditional Methods, Retention

\section{Introduction}

Learning a language is not easy and most students find it a very stressful experience. Surprisingly sometimes it is claimed that if students are laughing, playing a game and having fun, they are not really learning. In other words, they are just wasting time. These are statements that most of the time are heard or seen in different discussions about second language learning classes. But this is not always true. Of course, as stated in different research, language learning is a difficult task that requires constant effort especially for young learners, "games encourage learners to direct their energy towards language learning by providing them with meaningful contexts" (Buckby, 2006: 65). It is an element that connects all four skills together. We all have experimented or have seen the way students tend to forget or use words in a wrong context in learning a foreign language. As Huyen \& Nga, 2003 believe this is due to many factors: the most important of which are "Words are not properly stored in students' minds, they are not practiced enough, and they are not related to students own experiences and interests."
Therefore, it is intended to find ways to enhance the learning ability of students so that they can learn vocabulary in a more effective way. One of the innovative ways to teaching vocabulary items is using instructional games. Even though, some teachers claim that language games are a waste of time and prefer not to use them in classroom. In fact, games can provide EFL and ESL students more than that (Deesri, 2002). Among several strategies used to improve students' proficiency visual aids, CALL (Computer Assisted Language Learning), drama, role-play, and so on, are other useful strategies to promote students' language proficiency. Students seemed to learn new vocabulary more quickly and remember it better when it is applied in a more relaxed and comfortable environment especially when playing ESL games (Thi Thanh \& Nga, 2003). Games are played by rules in a way that helps students to learn the vocabulary items in a much more relaxed environment without the stress of the classroom, which the researcher believes helps the students to enhance their learning ability and memory. Games help student connect or relate the vocabulary items to their own experiences and interests. 


\section{Review of Literature}

There are various points of view on the nature of vocabulary learning. For many years, students and teachers have operated under a static and limited conception of vocabulary teaching. In this traditional view, vocabulary learning is considered as a set of words to be repeated until memorized. Although vocabulary teaching and learning were ignored, overwhelmingly, in certain methods of language teaching for some decades, there is now a widespread agreement upon the need for language learners to improve their knowledge of vocabulary (Coady \& Huckin, 1997). According to Skinner's theory, playing games can be presented as a kind of prize after learning which allows teachers to motivate learners to step forward (Pound, 2005). Wilkins (1972) is of the view that "Without grammar, little can be conveyed, without vocabulary, nothing can be conveyed". Previously, lexical aspects were subordinated and underrated to the study of grammatical structures (Nation, 1989). However, today, vocabulary is considered as the primary way towards learning a new language (Carter, 2001). Abdikhah (1998) claimed that from a psychological point of view, games have lots of benefits. They can reduce the inhibition of the learners particularly if they are co-operating in the games and not competing. The shy and nervous students, who do not show any tendency to contribute to class works, will feel more comfortable and will participate more easily and actively.

\section{Vocabulary Recollection}

Freeman (2000) states that Language games have real life communication features because the players are required to exchange ideas with one another and; moreover, they will have the opportunity to receive immediate feedback from their friends and also their teachers. "Games can lower anxiety; this will make the acquisition of input more likely" (Richard, Amato, 1988, p. 147). As said by Hansen (1994), one of the benefits of the language game is that it can provide shy students with opportunities to involve willingly in classroom activities. Lee (1996, as cited in Aslanabadi, 2013) lists some advantages of language games such as "a welcome break from the usual routine of the language class", "motivating and challenging", "effort of learning" and "language practice in the various skills" (Lee,1996: 35, as cited in Taheri, 2014).

Memory is critical in vocabulary learning and the benefits of revision and repetition have been clearly demonstrated in studies of vocabulary learning (O'Dell, 1997). According to Rubin (1960, p. 29), "learning is a process by which information is gained, stored, retrieved, and used." The word "use" can mean "interactional communication" and "vocabulary practice" (Schmitt, 1997). Therefore, teachers need to provide initial encoding of new words and then "subsequent retrieved experiences" (Rubin, 1987, p. 29). Also, it is suggested that if learners see or use a word in a way unlike the way they first saw it, then better learning is achieved. Schmitt (2000) also states that the amount of exposure to a language can affect second language vocabulary acquisition. In fact, research in vocabulary acquisition by Nation (1990) reveals that students need at least five to sixteen exposures to a new word before learning it. Besides, vocabulary acquisition is related to the effect of repetition on learning (Laufer, 1997). It can be said that repetition is one of the most effective ways to learn new words. Similarly, according to Carter and McCarthy (1990), new words are forgotten if they are not recycled in some way and moved to our long-term memory. In order to learn vocabulary, words have to be recycled numerous times. In fact, providing incidental encounters with words is one method to facilitate vocabulary acquisition (Sökmen, 1997).

\section{Methodology}

\subsection{Design}

The method of this study is quasi-experimental in nature, and the data are gathered in quantitative form. This method was chosen so that the researcher is allowed to control the assignment to the treatment condition, but using some criteria, other than random assignments as well.

\subsection{Participants}

All the subjects participated in this study were the preintermediate students of private Tarbiat high school in Chabahar. The number of subjects was 40 , all of whom were selected randomly and equally divided into two groups. One group was exposed to the traditional method of vocabulary teaching and the other group was exposed to instructional games. All of the subjects were males and between 12 to 13 years old. The teaching of the vocabularies in either the control group or the experimental group was carried out by the researcher himself. This way the risk of making mistakes is lowered and everything was observed by the researcher himself.

\subsection{Instruments}

Pre-test vocabulary test: A teacher-made test of 40 vocabulary items. The researcher conducted a test by which students' proficiency level was determined.

Post-test vocabulary test: It shows the effect of the treatments and the differences between the two groups.

Delayed Post-test: Delayed post-test was taken two weeks after the post-test. It was administered to both groups as a delayed post-test in order to measure the subjects' long term retention. Subjects of both groups took the delayed post-test unexpectedly.

\subsection{Procedure}

Two groups of students participated in the present study. One group consisting of 20 participants was selected randomly in order to investigate the effects of traditional teaching methods on vocabulary learning. Another group comprising 20 participants was chosen to see the influence of the instructional games on vocabulary learning. 
The students in both groups were asked to answer the questions in the test. After this stage, the students in the control group were taught new vocabulary items by means of traditional approaches like translation into and out of the target language, vocabulary memorization, pattern practice, keep notebook of new words, constant reading, and other rote learning activities. The students in the experimental group, however, were taught the new vocabulary items by instructional games. It is to be mentioned that the researcher used instructional games to reinforce and fix what had already been taught. All subjects were asked to take part in this task.

\section{Results}

Group statistics gained by students before and after using the training program are presented in tables for the control and experimental groups, respectively. As the statistics show, both groups have made progress in vocabulary knowledge.

Table 1. Group Statistics Prior to the Experiment.

\begin{tabular}{llllll}
\hline & Groups & N & Mean & $\begin{array}{l}\text { Std. } \\
\text { Deviation }\end{array}$ & $\begin{array}{l}\text { Std. Error } \\
\text { Mean }\end{array}$ \\
\hline \multirow{2}{*}{ Groups } & Experimental & 20 & 6.7000 & 2.69698 & .60306 \\
& Control & 20 & 6.7000 & 2.10513 & .47072 \\
\hline
\end{tabular}

Table 2. Independent T-test for Control and Experimental Groups on pretest.

\begin{tabular}{|c|c|c|c|c|c|c|c|c|c|c|}
\hline \multicolumn{11}{|c|}{ Levine's Test for Equality of Means } \\
\hline & & $\begin{array}{l}95 \% \\
\text { Confidence }\end{array}$ & Sig. & $\mathbf{t}$ & df & Sig.(2-tailed) & Mean Difference & Std. Error Difference & Lower & Upper \\
\hline \multirow[t]{2}{*}{ Scores } & $\begin{array}{l}\text { Equal } \\
\text { variances } \\
\text { assumed }\end{array}$ & 1.127 & 0.294 & .000 & 38 & 1.000 & .0000 & 0.765 & -1.548 & 1.548 \\
\hline & not assumed & & & .000 & 35.884 & 1.000 & .0000 & 0.765 & -1.551 & 1.551 \\
\hline
\end{tabular}

To see whether the two groups were at the same level of ability, a forty-item vocabulary test was administered to both, the Control and the Experimental groups. As the results clearly show, the two groups were at the same level of proficiency. The results of the analysis are shown in the above Tables.

Table 2 shows the results of the independent t-test for the control group and the experimental group. As it can be concluded from the table, the mean score of the control group is 6.7 and the mean score for the experimental group is 6.7. Close consideration toward the mean difference of the two groups $(.000)$ and, of course, the $p$ value $(p=.000<.05)$ shows that the groups are almost the same or, at most, there is not a significant difference between them. The above table shows the results in a more tangible manner.
Also a comparison of the control group and the experimental group on posttest was done to see whether there was any kind of change in the experimental group. In this section, we are about to see which group performed better, and as a result which method, is more efficient in teaching vocabulary items to Iranian students. The results, just like the previous parts, are presented through tables.

Table 3. Group Statistics for Control and Experimental Groups on Posttest.

\begin{tabular}{llllll}
\hline Group2 & N & Mean & $\begin{array}{l}\text { Std. } \\
\text { Deviation }\end{array}$ & $\begin{array}{l}\text { Std. Error } \\
\text { Mean }\end{array}$ \\
\hline \multirow{2}{*}{ Score2 } & Experimental 20 & 18.1 & 1.518 & 0.339 \\
& Control & 20 & 18.3 & 1.380 & 0.308 \\
\hline
\end{tabular}

Table 4. Independent T-test for Control and Experimental Groups on Posttest.

\begin{tabular}{|c|c|c|c|c|c|c|c|c|c|c|}
\hline \multicolumn{4}{|c|}{ Levene's Test for Equality of Variances } & \multicolumn{7}{|c|}{ t-test for Equality of Means } \\
\hline & & \multirow{2}{*}{$\mathbf{F}$} & \multirow{2}{*}{ Sig. } & \multirow{2}{*}{$\mathbf{t}$} & \multirow{2}{*}{ df } & \multirow{2}{*}{$\begin{array}{l}\text { Sig. (2- } \\
\text { tailed) }\end{array}$} & \multirow{2}{*}{$\begin{array}{l}\text { Mean } \\
\text { Difference }\end{array}$} & \multirow{2}{*}{$\begin{array}{l}\text { Std. Error } \\
\text { Difference }\end{array}$} & \multicolumn{2}{|c|}{ 95\% Confidence Interval of the Difference } \\
\hline & & & & & & & & & Lower & Upper \\
\hline \multirow{2}{*}{ Score2 } & $\begin{array}{l}\text { Equal variances } \\
\text { assumed }\end{array}$ & .016 & .899 & -.436 & 38 & .665 & -.200 & .45833 & -1.128 & .72886 \\
\hline & $\begin{array}{l}\text { Equal variances } \\
\text { not assumed }\end{array}$ & & & -.436 & 37.660 & .665 & -.200 & .45833 & -1.129 & .72913 \\
\hline
\end{tabular}

According to the statistics in the above table (Table 4), the mean score of the control group on the posttest is 18.3 , while that of the experimental group is 18.01. The mean difference of the two groups, as the table shows, is -.200 and since the $p$ value is $\mathrm{p}=.000<\mathrm{p}=.05$, it can be concluded that both the experimental and the control groups have performed significantly better on the posttest. Even though the control group did slightly better. It wasn't something unexpected, the process of learning vocabulary is not something to be learned overnight, and it takes time and effort.

In order to see changes (if any) in the experimental and control group with regard to the posttest scores of subjects, one t-test was conducted to compare the results. The results are presented in the following table:

Table 5. One-Sample Statistics of control and Experimental Group on delayed posttest.

\begin{tabular}{lllll}
\hline & $\mathbf{N}$ & Mean & $\begin{array}{l}\text { Std. } \\
\text { Deviation }\end{array}$ & $\begin{array}{l}\text { Std. Error } \\
\text { Mean }\end{array}$ \\
\hline Control & 20 & 12.8000 & 4.07302 & .91075 \\
Experimental & 20 & 16.3500 & 1.75544 & .39253 \\
\hline
\end{tabular}


Table 6. One-Sample Test of control and Experimental Group on delayed posttest.

\begin{tabular}{|c|c|c|c|c|c|c|}
\hline & \multicolumn{6}{|c|}{ Test Value $=0$} \\
\hline & \multirow{2}{*}{$\mathbf{t}$} & \multirow{2}{*}{ df } & \multirow{2}{*}{ Sig. (2-tailed) } & \multirow{2}{*}{ Mean Difference } & \multicolumn{2}{|c|}{ 95\% Confidence Interval of the Difference } \\
\hline & & & & & Lower & Upper \\
\hline Control & 14.054 & 19 & .000 & 12.80000 & 10.8938 & 14.7062 \\
\hline Experimental & 41.653 & 19 & .000 & 16.35000 & 15.5284 & 17.1716 \\
\hline
\end{tabular}

As the table above suggests, the experimental group has made a significant progress during the course of study. The mean score of this group on delayed posttest was 16.35. In comparison to the control group, the experimental group has made a significant progress.

\section{Conclusion}

One of the aims of this study was to help learners learn vocabulary items more productively and with more ease. Therefore, games were the tools to test the hypothesis at hand. Memorizing vocabulary items has always been a very hard and time consuming matter. Students struggle to memorize long lists of vocabulary items and finally end up not remembering most of them after a short time. As well as for teachers who constantly have to try and make the students study long lists of vocabulary items as much as they can and at the same time try to keep them motivated in a learning situation. On the other hand, some teachers think that language games are a waste of time and would rather not use them in class.

According to the results and contrary to the researcher's expectation, there was no significant difference between the control and experimental groups in the posttest. The researcher hypothesized that the experimental group would have a much greater results compared to the control group. However, after two weeks, a delayed posttest was taken and there was a significant difference between the control and experimental group in the delayed posttest. The results showed that the long term retention of students in the experimental group had improved significantly. These results proved that playing games as a tool for teaching vocabulary items can in fact improve the long term retention of learners.

In the end, it was concluded that the training program significantly increased vocabulary knowledge of the subjects. However, no significant difference was found in short term retention of both groups, as both programs made significant progress in the subjects on the posttest. In brief, the delayed posttest showed that there was a significant difference between the control group and the experimental group.

\section{References}

[1] Deesri, A. (2002). Games in the ESL and EFL Class. The Internet TESL Journal.

[2] Abdikhah, S. (1998). "The effect of language games on vocabulary improvement." Unpublished MA thesis, Tehran: Tarbiat Modarres University.
[3] Aslanabadi, H. (2013). "The effect of games on improvement of Iranian EFL vocabulary knowledge in kindergartens." International Review of Social Sciences and Humanities.

[4] Buckby, M. (2006). Games for language learning. Cambrideg: Cambridge University Press, 65.

[5] Carter, R. (2001). Vocabulary. In R. Carter and D.Nunan (Eds.). The Cambridge Guide to Teaching English to Speakers of Other Languages. Cambridge: Cambridge University Press., 40-47.

[6] Coady, J. (1997). Second Language Vocabulary Acquisition. Cambridge: Cambridge University Press, Freeman.

[7] Freeman, D. L. (2000). Techniques and Principles in Language Teaching (2nd ed.). London: Oxford University Press.

[8] Hansen, M. (1994). Grajmy w jezyku francuskim. Jezyki Obce w Szkole.

[9] Laufer, B. (1997). "Memorizing new words: Does teaching have anything to do with it?" RELC journal, 28(1), 89108.

[10] McCarthy, M. (1990). Lang Teach Vocabulary. UK: Oxford University Press.

[11] Nation, I. S. (1990). Teaching and Learning Vocabulary. New York: Newbury House Publishers.

[12] Nation, P. (1989). Dictionaries and Language Learning. In: Tickoo (Ed.), Learners' Dictionaries: State of the Art. Anthology Series 23.

[13] Nga, N. T. (2003). "Learning vocabulary through games." Asian EFL Journal.

[14] O'Dell, F. (1997). Vocabulary: Description, Acquisition, and Pedagogy. Cambridge: Cambridge University Press.

[15] Pound, L. (2005). How Children Learn. London: Step Forward Publishing, Ltd.

[16] Richard-Amato, P. A. (1988). Making it Happen: Interaction in the Second Language classroom: From. New York: Longman., 147.

[17] Robinson, K. (1960). English Teaching in South-east Asia. London: Evan Brothers, Ltd.

[18] Rubin, J. (1987). Learner Strategies in Language Learning (pp. 21-32). New York: Prentice Hall.

[19] Schmitt, N. (1997). Vocabulary: Description, acquisition, and pedagogy. Cambridge: Cambridge University Press., 203.

[20] Schmitt, N. (2000). Vocabulary in Language Teaching. Cambridge: Cambrifge University press. 
[21] Sökmen, A. J. (1997). Current Trends in Teaching Second Language Vocabulary. Cambridge: Cambridge University Press.

[22] Taheri, M. (2014). "The effect of using language games on vocabulary retention of Iranian elementary EFL learners." Journal of Language Teaching and Research, Vol. 5, No. 3, 544-549.
[23] Wilkins, D. A. (1972). Linguistics in Language Teaching. Cambridge, MA: MIT Press., 111.

[24] Huyen N, NgaK.2003.Learning Vocabulary through Games. Cambridge: Cambridge University Press. 